\title{
Trophoblastic Tumor
}

National Cancer Institute

\section{Source}

National Cancer Institute. Trophoblastic Tumor. NCI Thesaurus. Code C3422.

A gestational or non-gestational neoplasm composed of neoplastic trophoblastic cells.

Representative examples include hydatidiform mole and choriocarcinoma. 